\title{
Relationship between social media addiction, game addiction and family functions
}

\author{
Ebru Yayman ${ }^{1}$, Okan Bilgin ${ }^{2}$ \\ ${ }^{1} \mathrm{Ph} . D$ Program, İstanbul Sabahattin Zaim University, Turkey \\ ${ }^{2}$ Department of Education Sciences, Zonguldak Bülent Ecevit University, Turkey
}

\section{Article Info \\ Article history: \\ Received Apr 20, 2020 \\ Revised Sep 24, 2020 \\ Accepted Oct 25, 2020}

\section{Keywords:}

Adolescents

Family functions

Game addiction

Social media addiction

\begin{abstract}
This study examined the relationship between social media addiction, game addiction and family functions in adolescents. Respondent of this study is 762 students studying at four different high schools of the province of İstanbul. In the study, Pearson Moment Correlation Coefficient was found to determine the level of relationships between social media addiction, game addiction and family functions in adolescents. The effects of social media addiction and game addiction in adolescents on family functions were examined with regression analysis technique. When the relationships between social media addiction, game addiction and family functions in adolescents were examined, a positive relationship was found between social media and game addiction, while a positive significant relationship was found between both social media and game addiction and unhealthy family functions. In addition, it was also concluded that social media addiction and game addiction in adolescents were significant predictors of all subdimensions of family functions.
\end{abstract}

This is an open access article under the CC BY-SA license.

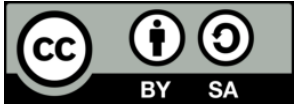

\section{Corresponding Author:}

Okan Bilgin,

Department of Educational Sciences, Zonguldak Bülent Ecevit University, Kdz. Ereğli, Zonguldak, Turkey.

Email: bilgin.okan@gmail.com

\section{INTRODUCTION}

Technology use has two main objectives. These are hedonic use and utilitarian use. The aim is fun in hedonic use. Individuals use technology for having a nice time, distraction, entertainment, escape or looking for adventure and fantasy. However, all these conveniences provided by technology prepare the ground for technology addiction in individuals [1]. Technology addiction is a general concept that includes different kinds of addictions. One of these is social media addiction, which is one of the addiction types most frequently seen especially in adolescent groups. Addiction can be defined as the inability to stop using or control a substance or behavior [2]. Individuals may be addicted to many substances such as cigarettes, alcohol, and drugs. However, addiction should not be considered only as addiction to cigarettes, alcohol, drugs, etc. In addition, behavior-based food addiction, game addiction, sex addiction, computer addiction, smartphone addiction, television addiction, shopping addiction, internet addiction, etc. addictions can also be mentioned. Technology addiction is also considered as a behavioral addiction $[3,4]$.

Adolescents consider the internet and thus social media use as an area they take refuge in order to escape from their identities they have problems with in the real world and the responsibilities waiting for them during the period of identity acquisition [5]. A report was prepared by the Ministry of Communications Internet Board, which aimed to find out the "social media networking sites habits of use in children aged 
between 9 and 16" and which was carried out with the support of Middle East Technical University and Information Technologies and Communications Authority Telecommunications Communication Presidency. According to February 2011 report, $70 \%$ of the adolescents between the ages of 9 and 16 used the internet at least once a day, $66 \%$ used social networks at least once a day and spent an average of 72 minutes here. This rate shows that adolescents spend a great deal of the time they spend on the internet in social media networks. This popularity has caused social media to be discussed with its benefits and harms [6,7].

According to Ünal [8], social media addiction is a psychological problem which develops with cognitive, affective and behavioural processes and which causes problems such as preoccupation, mood regulation, repetition and conflict in many areas of an individual's daily life such as private, professional/academic and social areas. It can be seen that adolescents are more affected by this type of addiction when compared with other age groups. The most important reason why adolescents are more affected by the negative influences of the internet when compared with other age groups is the fact that they have not completed their developmental process yet [5, 9]. Researches have reported that the most important reason for adolescents' use of social media is entertainment and communication. Their second purpose is to search for information [10,11]. In another study conducted, the relationship between internet and social media addiction and internet use behaviour patterns was examined and a significant relationship was found between these two behaviours. The most important reason why especially adolescents develop addiction in this regard is for communication and entertainment purposes, as stated in results of similar studies [12]. Adolescents develop unhealthy internet use behaviours in order to fight their adaptation problems and low self-esteem in this period [13]. Adolescents may experience difficulties due to their feelings and thoughts and as a result, they may turn to the group of friends in order to get away from the problems and overcome them. In this period, social approval and peer acceptance may be at the forefront for adolescents. Technology can provide opportunities to meet the social approval and peer acceptance expectations of adolescents through communication applications $[14,15]$. In addition, the use of technologies such as the internet, social media, smartphones and digital games is more common among adolescents. This situation can make adolescents more sensitive to technological addictions [16].

One of the most common problems in adolescents after social media use is digital gaming. Especially individuals in the early periods of adolescence use digital games more frequently. Digital games, which are used for purposes such as having a good time, entertainment, pleasure, mind exercise can lead the path to digital game addiction if too much time is spent on digital games [17]. Digital game addiction has been called a situation with consequences such as the individual's inability to stop playing for a long time, associating the game with real life, hindering the responsibilities imposed on the individual due to playing game and preferring gaming to other activities [18]. So far, there is no standard single definition of digital game addiction in adolescents. However, digital game addiction is accepted as a type of behaviour addiction. It is expressed as an individual's continuing to play game for a long time without being able to control himself despite being harmed by the action. Digital game addiction can be defined with actions such as associating the game played with real life, not being able to fulfil the responsibilities due to time allocated for the game and the importance of the game in the mind, preferring to play game instead of other responsibilities and the individual's not being able to prevent himself from doing otherwise [19].

Gaming disorder, which is defined as playing with other players frequently and repetitively, is included in DSM-V. Some symptoms can easily be noticed in game addicts. These are a large number of cognitive and behavioural symptoms such as playing games that last as long as 8-10 hours a day, inability to maintain control in this behaviour, reacting with anger even to constructive criticism against this situation, breaking ties with close relationships, delaying or not doing basic needs and activities [20]. All these symptoms cause negative effects for adolescents in developmental period. Other defined effects are malnutrition, appearance of suicidal and deadly behaviours, disconnection in social relationships, problems with family and significant decreases in school success [21-24]. Family problems, one of these effects, can bring along problems that cannot be solved in the future.

Adolescents' excessive use of social media and digital games, or the formation of addiction creates disconnections in family ties by having a negative effect on human relationships and especially family relationships. Adolescents can see technology as an escape from the problems of real life. However, it is debatable how healthy internet use for coping purposes is. As a result of intense social media or digital games, the communication between adolescents and their parents decrease gradually and turn into a defensive or aggressive type of communication and thus the communication within the family is negatively influenced [25]. In a study conducted with 1228 middle school 5th and 8th grade students in Taiwan in 2004, it was found that computer games cause problems and conflicts in the family and affect academic success. It has been observed that adolescents who have problems with their families during adolescence are also prone to game addiction [26]. In another study, it was observed that adolescents with internet addiction developed anxious attachment style towards their families [27]. 
Adolescents who use social media and play digital games are noticed by their families over time and the communication resources between the adolescent and family members may experience difficulties in the process. As a result of this research, the importance of social media and game addiction in adolescents will be emphasized as to how the action-reaction dynamics of the family are formed as a process and how this process will be managed more accurately by raising awareness. As a result of the findings obtained, it is thought that this research will be an important research resource in raising awareness and education of adolescents and families.

The general aim of this study is to determine the relationships between social media addiction, gaming addiction and family functions in adolescents. In line with this purpose, it was examined whether there is significant relationship between these concepts. The study also examined social media and gaming addiction's levels of predicting family functions in adolescents.

\section{RESEARCH METHOD}

\subsection{Research model}

In this study, relational survey model, which is one of the general survey models, was used. Survey models are researches which aim to describe a situation that has existed in the past and still continues to exist today. "Relational survey model," which is one of the survey models, is a research model which aims to find out whether the change between two or more variables exists together or to find out the level of the change [28].

\subsection{Population and sample}

The population of the study consists of adolescents studying in the province of İstanbul during 2018-2019 academic year. The sample of the study consists of 762 adolescents studying in four different high schools in the province of İstanbul during 2018-2019 academic year. The distribution of the adolescents who participated in the study by gender is shown in Table 1 . When Table 1 is examined, it can be seen that 379 $(49.7 \%)$ of the students are female and $383(50.3 \%)$ are male.

Table 1. Distribution of the students who participated in the study by gender

\begin{tabular}{ccc}
\hline Gender & f & $\%$ \\
\hline Female & 379 & 49.7 \\
Male & 383 & 50.3 \\
\hline
\end{tabular}

\subsection{Data collection instruments}

In this study, the data were collected with "Social Media Addiction Scale for Adolescents," "Game Addiction Scale Short Form for Adolescents" and "Family Assessment Device."

\subsubsection{Social media addiction scale for adolescents (SMASA)}

Social Media Addiction Scale for Adolescents was developed by Özgenel, Canbolat and Ekşi [29]. As a result of the exploratory factor analysis conducted on the 27-item draft scale, a 9-item and single factor structure was obtained. High scores taken from the 5-Likert type scale show high levels of social media addiction in adolescents. It has been stated that the 9-item and single factor scale explains $56.787 \%$ of the total variance. In tests conducted for reliability analysis, it was found that the Cronbach's Alpha coefficient of the scale was 0.904 . With this version, it can be said that the scale is a valid and reliable measurement assessment that can be used to find out social media addiction level in adolescents.

\subsubsection{Game addiction scale short form for adolescents}

Game Addiction Scale Short Form for Adolescents was developed by Anlı and Taş [30]. As a result of the factor analysis conducted to find out the construct validity of the scale, it was found that the scale had 9 items and a single factor. High scores are taken from the 5-Likert type scale show high levels of game addiction. Test takers are asked to choose one from the options "Never", "Rarely", "Sometimes", "Frequently", "Always". While it was found that the single factor explained $42.806 \%$ of the scale's total variance, it was found that common variances of the scale items ranged between .191 and .579, factor loadings of the items ranged between .437 and .761 and item total correlations ranged between .340 and .653 . Cronbach's Alpha coefficient conducted for the reliability analysis of the scale was found as .81. 


\subsubsection{Family assessment device}

Family Assessment Device, which was developed by Epstein et al. [31] to assess various dimensions of family functioning, was adapted to Turkish by Bulut [32]. The scale includes 60 items and 7 subdimensions as problem solving, communication, roles, affective responsiveness, affective involvement, behaviour control and general functioning. The scale is a 4-Likert type scale. The items in the scale have two types of expressions. These are items which show healthiness and unhealthiness. In all items, 1 represents the healthiest response, while 4 represents the unhealthiest response. As the scores calculated for each subdimension get closer to 4, it is interpreted as increase in unhealthiness. Theoretically, 2 has been determined as distinctive score. Scores lower than 2 show healthy family functions, while scores higher than 2 show unhealthy family functions. Internal consistency coefficients of the items assessed with Cronbach's alpha for reliability analysis ranged between .38 and .86 [32].

\subsection{Data analysis}

In data analysis, use of parametric tests depends on meeting some assumptions. For this, the data should be normally distributed and the variables should be homogeneous. In order to determine the data analysis methods to be used in the study, first the data were examined in terms of normality distribution. As a result of the normality assumption analysis, the data were found to be normally distributed and it was decided to use parametric tests in data analysis. SPSS 25.00 program was used in data analysis. Significant differences in variables of the study were analysed with Independent Samples T test for paired groups, while differences were analysed with One-way ANOVA for more than three groups. The association between the variables was calculated with Pearson correlation. Regression analysis technique was used to find out the predictive power of the relationship between social media addiction, game addiction and family functions in adolescents.

\section{RESULTS AND DISCUSSION}

This part of the study includes results of the analyses conducted based on the problem situations determined regarding the aims of the study. The values regarding the correlations between social media, game addiction and family functions in adolescents are shown in Table 2. Table 2 shows the correlation coefficients between social media, game addiction and family functions sub-dimension scores of the adolescents who constituted the sample group of the study. When the associations between the variables are examined, it can be seen that there are positive and low significant associations between both social media addiction and game addiction and all the sub-dimensions of family functions. There are also low and positive associations between game addiction and social media addiction.

Table 2. Correlations between social media addiction, game addiction and family functions sub-dimensions

\begin{tabular}{|c|c|c|c|c|c|c|c|c|c|}
\hline & $\begin{array}{c}\text { Game } \\
\text { addiction }\end{array}$ & $\begin{array}{c}\text { Social media } \\
\text { addiction }\end{array}$ & $\begin{array}{c}\begin{array}{c}\text { Problem } \\
\text { solving }\end{array} \\
\end{array}$ & Communication & Roles & $\begin{array}{c}\text { Affective } \\
\text { responsiveness }\end{array}$ & $\begin{array}{c}\text { Affective } \\
\text { involvement }\end{array}$ & $\begin{array}{c}\text { Behaviour } \\
\text { control }\end{array}$ & $\begin{array}{l}\text { General } \\
\text { functions }\end{array}$ \\
\hline Game addiction & 1 & & & & & & & & \\
\hline $\begin{array}{l}\text { Social media } \\
\text { addiction }\end{array}$ & $.332 * *$ & 1 & & & & & & & \\
\hline $\begin{array}{l}\text { Problem } \\
\text { solving }\end{array}$ & $.154 * *$ & $.173 * *$ & 1 & & & & & & \\
\hline Communication & $.177 * *$ & $.240 * *$ & $.561^{* *}$ & 1 & & & & & \\
\hline Roles & $.200 * *$ & $.282 * *$ & $.424 * *$ & $.504 * *$ & 1 & & & & \\
\hline $\begin{array}{c}\text { Affective } \\
\text { responsiveness }\end{array}$ & $.140 * *$ & $.233^{* *}$ & $.432 * *$ & $.597 * *$ & $.537 * *$ & 1 & & & \\
\hline $\begin{array}{l}\text { Affective } \\
\text { involvement }\end{array}$ & $.122 * *$ & $.215^{* * *}$ & .013 & $.159 * *$ & $.336^{* *}$ & $.313 * *$ & 1 & & \\
\hline $\begin{array}{l}\text { Behaviour } \\
\text { control }\end{array}$ & $.177 * *$ & $.202^{* *}$ & $.292 * *$ & $.351^{* *}$ & $.409 * *$ & $.361 * *$ & $.229 * *$ & 1 & \\
\hline $\begin{array}{l}\text { General } \\
\text { functions }\end{array}$ & $.189^{* *}$ & $.292 * *$ & $.614 * *$ & $.689^{* *}$ & $.627 * *$ & $.724 * *$ & $.313^{* *}$ & $.426 * *$ & 1 \\
\hline
\end{tabular}

In this study, the effects of adolescents' social media addiction and game addiction on family functions were also examined. While examining the results of purpose, the effects of social media and game addiction on the sub-dimensions of family functions were examined with regression analysis technique. Regression analysis results related to the problem-solving sub-dimension of family functions are shown in Table 3. 
Table 3. Regression analysis results of problem solving variable

\begin{tabular}{ccccccc}
\hline Step & Predictive variable & $\mathrm{R}$ & $\mathrm{R}^{2}$ & Change in $\mathrm{R}^{2}$ & $\mathrm{~F}$ & $\mathrm{P}$ \\
\hline 1 & Game addiction & .154 & .024 & .024 & 18.568 & 0.000 \\
2 & Game, Social Media Addiction & .202 & .041 & .017 & 13.280 & 0.000 \\
\hline Dependent Variable: Problem Solving & & & & &
\end{tabular}

When Table 3 is examined, it can be seen that game addiction alone predicts problem solving, which is one of the sub-dimensions of family functions, with a rate of $2 \%$. It was found that while social media addiction alone explained $2 \%$ of problem solving, the common effect of social media and game addiction on problem solving was $4 \%$. Regression analysis results related to the communication sub-dimension of family functions are shown in Table 4.

Table 4. Regression analysis results of communication variable

\begin{tabular}{ccccccc}
\hline Step & Predictive variable & $\mathrm{R}$ & $\mathrm{R}^{2}$ & Change in $\mathrm{R}^{2}$ & $\mathrm{~F}$ & $\mathrm{P}$ \\
\hline 1 & Game addiction & .177 & .031 & .031 & 24.656 & 0.000 \\
2 & Game, Social Media Addiction & .262 & .068 & .037 & 30.149 & 0.000 \\
\hline
\end{tabular}

Dependent Variable: Communication

When Table 4 is examined, it can be seen that game addiction alone predicts communication, which is one of the sub-dimensions of family functions, with a rate of $3 \%$. It was found that while social media addiction alone explained $4 \%$ of communication sub-dimension, the common effect of social media and game addiction on communication was 7\%. Regression analysis results related to the roles sub-dimension of family functions are shown in Table 5.

Table 5. Regression analysis results of roles variable

\begin{tabular}{ccccccc}
\hline Step & Predictive variable & $\mathrm{R}$ & $\mathrm{R}^{2}$ & Change in $\mathrm{R}^{2}$ & $\mathrm{~F}$ & $\mathrm{P}$ \\
\hline 1 & Game addiction & .200 & .040 & .040 & 31.784 & 0.000 \\
2 & Game, Social Media Addiction & .304 & .092 & .052 & 43.666 & 0.000 \\
\hline Dependent Variable: Roles
\end{tabular}

When Table 5 is examined, it can be seen that game addiction alone predicts roles, which is one of the sub-dimensions of family functions, with a rate of $4 \%$. It was found that while social media addiction alone explained $5 \%$ of roles sub-dimension, the common effect of social media and game addiction on roles was $9 \%$. Regression analysis results related to the affective responsiveness sub-dimension of family functions are shown in Table 6.

Table 6. Regression analysis results of affective responsiveness variable

\begin{tabular}{ccccccc}
\hline Step & Predictive variable & $\mathrm{R}$ & $\mathrm{R}^{2}$ & Change in $\mathrm{R}^{2}$ & $\mathrm{~F}$ & $\mathrm{P}$ \\
\hline 1 & Game addiction & .140 & .020 & .020 & 15.292 & 0.000 \\
2 & Game, Social Media Addiction & .242 & .059 & .039 & 31.338 & 0.000 \\
\hline \multicolumn{7}{l}{ Dependent Variable: Affective responsiveness }
\end{tabular}

When Table 6 is examined, it can be seen that game addiction alone predicts affective responsiveness, which is one of the sub-dimensions of family functions, with a rate of $2 \%$. It was found that while social media addiction alone explained $4 \%$ of affective responsiveness sub-dimension, the common effect of social media and game addiction on affective responsiveness was $6 \%$. Regression analysis results related to the affective involvement sub-dimension of family functions are shown in Table 7.

Table 7. Regression analysis results of affective involvement variable

\begin{tabular}{ccccccc}
\hline Step & Predictive variable & $\mathrm{R}$ & $\mathrm{R}^{2}$ & Change in $\mathrm{R}^{2}$ & $\mathrm{~F}$ & $\mathrm{P}$ \\
\hline 1 & Game addiction & .122 & .015 & .015 & 11.514 & 0.001 \\
2 & Game, Social Media Addiction & .221 & .049 & .034 & 27.246 & 0.000 \\
\hline
\end{tabular}


When Table 7 is examined, it can be seen that game addiction alone predicts affective involvement, which is one of the sub-dimensions of family functions, with a rate of $2 \%$. It was found that while social media addiction alone explained 3\% of affective involvement sub-dimension, the common effect of social media and game addiction on affective involvement was 5\%. Regression analysis results related to the behaviour control sub-dimension of family functions are shown in Table 8.

Table 8. Regression analysis results of behaviour control variable

\begin{tabular}{ccccccc}
\hline Step & Predictive variable & $\mathrm{R}$ & $\mathrm{R}^{2}$ & Change in $\mathrm{R}^{2}$ & $\mathrm{~F}$ & $\mathrm{P}$ \\
\hline 1 & Game addiction & .177 & .031 & .031 & 24.663 & 0.000 \\
2 & Game, Social Media Addiction & .233 & .054 & .023 & 18.480 & 0.000 \\
\hline Dependent Variable: Behaviour control
\end{tabular}

When Table 8 is examined, it can be seen that game addiction alone predicts behaviour control, which is one of the sub-dimensions of family functions, with a rate of $3 \%$. It was found that while social media addiction alone explained $2 \%$ of behaviour control sub-dimension, the common effect of social media and game addiction on behaviour control was 5\%. Regression analysis results related to the general functioning sub-dimension of family functions are shown in Table 9.

Table 9. Regression analysis results of general functioning variable

\begin{tabular}{ccccccc}
\hline Step & Predictive variable & $\mathrm{R}$ & $\mathrm{R}^{2}$ & Change in $\mathrm{R}^{2}$ & $\mathrm{~F}$ & $\mathrm{P}$ \\
\hline 1 & Game addiction & .189 & .036 & .036 & 28.242 & 0.000 \\
2 & Game, Social Media Addiction & .308 & .095 & .059 & 49.345 & 0.000 \\
\hline
\end{tabular}

Dependent Variable: General functioning

When Table 9 is examined, it can be seen that game addiction alone predicts general functioning, which is one of the sub-dimensions of family functions, with a rate of $4 \%$. It was found that while social media addiction alone explained $6 \%$ of general functioning sub-dimension, the common effect of social media and game addiction on general functioning was $10 \%$.

As a result of the analysis conducted within the scope of the study, it was found that there was a positive and statistically significant association between game addiction and social media addiction, a positive and statistically significant association between game addiction and unhealthy family functions, and a positive and statistically significant association between social media addiction and unhealthy family functions. In one of the similar studies, a statistically significant negative association was found between game addiction and positive family functions [33]. In another similar study, the association between social media addiction and family relationships was examined and a negative statistically significant difference was found between social media addiction and positive family relationships [34]. In another similar study, a negative statistically significant difference was found between game addiction and healthy family functions [35]. While family relationships in supportive family environment affect game addiction negatively, family relationships in prohibitive family environment affect game addiction positively [33] When the results of the study and similar results in literature are examined, it can be seen that similar results were found. Unlike the results of the present study, no statistically significant association was found between social media addiction and family communication in a study conducted [36].

\section{CONCLUSION}

To summarize the findings of the study, game addiction and social media addiction were used as predictive of all sub-dimensions of family functions in this study. Of the regressed variables, social media and game addiction significantly predicted all sub-dimensions of family functions. While it was found that social media and game addiction explained sub-dimensions of family functions within a range of $4 \%$ and $7 \%$ in general, the highest effects were found in general functioning and roles sub-dimensions. While social media and game addiction predicted $10 \%$ of general functioning, they predicted $9 \%$ of roles sub-dimension. While social media addiction and game addiction are negatively associated with healthy family functions, they are positively associated with unhealthy family functions. There is also a positive association between social media addiction and game addiction and social media addiction increases game addiction, while game addiction increases social media addiction. As a result, it can be said that increased use of social media and game addiction especially in adolescents have a direct and negative effect on family relationships.

Int. J. Eval. \& Res. Educ. Vol. 9, No. 4, December 2020: 979 - 986 
The increasing social media and game addiction in adolescents can cause family interaction to decrease gradually, family problems to increase and family relationships to decrease. With such a process, the members of the family are faced with an introvert family structure. Parents who do not have a healthy communication style can start having much more serious problems with their adolescents about solving the problems that arise in children in such a period. All kinds of problems that occur in family structure can cause different orientations in children who have to grow up in an unhealthy family environment. It can be said that in addition to cultural and moral breakdowns, individuals who do not have a healthy adolescence can have problems in their future lives.

Adolescents' social media use and gaming time should be supervised by families in a controlled and informative way. Not only in high schools, but in relevant units of all education level, education support should be provided to parents and students in schools regarding conscious and safe use of social media and social media and game addiction by "Psychological Counselling and Guidance" experts. In order to reach large masses with instructive activities about the existence, reasons and all destructive effects of social media and game addiction, more effective works should be carried out by the state, especially by the Family and Social Services unit of the Ministry of Family. Parents should communicate with their children with a supportive family approach rather than a prohibitive family approach.

\section{ACKNOWLEDGEMENTS}

This study was produced from one of the author's master's thesis in discipline of Psychological Counseling and Guidance at Istanbul Sabahattin Zaim University.

\section{REFERENCES}

[1] M. Modahl, Now or Never: How companies must change today to win the battle for internet concumer, 1 st. Ed. New York: Harper Collins Publishers, 2001.

[2] Egger O, and Rauterberg M., "Internet behaviour and addiction," Master's thesis, Zurih, Work \& Organisational Psychology Unit (IfAP), Swiss Federal Institute of Technology (ETH), 1996.

[3] Greenfield DN., "Virtual addiction: Sometimes new technology can create new problems," 2008. [Online]. Available: http://www.virtual-addiction.com/pdf/ nature_internet_addiction.pdf

[4] Kim S, and Kim R., "A study of internet addiction: Status, Causes, and Remedies- Focusing on the alienation factor," International Journal of Human Ecology, vol. 3, no. 1, pp. 1-19, 2002.

[5] S.C. Yang, and C.J. Tung, "Comparison of internet addicts and non-addicts in Taiwanese high school," Computers in Human Behavior, vol. 23, no. 1, pp. 79-96, 2007.

[6] H. B. Hatipoğlu, "Sosyal Medya ve Ticaret Hayatına Etkileri," CIO Club Dergisi, pp. 71-74, 2009.

[7] M. Koç and M. Karabatak, "Sosyal Ağların Öğrenciler Üzerindeki Etkisinin Veri Madenciliği Kullanılarak İncelenmesi," 5 Uluslararası Bilgisayar ve Öğretim Teknolojileri Sempozyumu. Firat Üniversitesi, Elazı̆̆, 2011.

[8] T.Ü. Ünal, "Sosyal Medya Bağımlılı̆̆ı: Üniversite Öğrencileri Üzerine Bir Araştırma," Doktora Tezi, Marmara Üniversitesi, İstanbul, 2015.

[9] C. Tsai and S. J. Lin, "Analysis of attitudes toward computer networks and internet addiction of Taiwanese adolescents," Cyberpsychology \& Behavior, vol. 4, no. 3, pp. 373-376, 2001.

[10] C. Tsai and S. J. Lin, "Internet addiction of adolescents in Taiwan: an interview study," CyberPsychology \& Behavior, vol. 6, no. 6, pp. 649-652, 2003.

[11] F. Bayraktar and Z. Gün, "Incidence and correlates of internet usage among adolescents in North Cyprus," Cyberpsychology \& Behavior, vol. 10, no. 1, pp. 191-197, 2007.

[12] C. Chou, et al., "A review of the research on internet addiction," Educational Psychology Review, vol. 17, no. 4, pp. 363-388, 2005.

[13] S.J. Lin and C.C. Tsai. "Sensation seeking and internet dependence of Taiwanese high school adolescents," Computers in human behavior, vol. 18, no. 4, pp. 411-426, 2002.

[14] Subrahmanyan K, and Lin G., "Adolescents on the net: internet use and well-being," Adolescence, vol. 42, no. 168, pp. 659-77, 2007.

[15] Griffiths MD., "A components model of addictionwith in a biopsychosocial framework," Journal of Substance Use, vol. 10, no. 4, pp. 191-97, 2005.

[16] Valkenburg PM, and Peter J., "Online communication among adolescents: An integrated model of its attraction, opportunities, and risks," J Adolesc Health, vol. 48, no. 2, pp. 121-27, 2011.

[17] E. Yiğit and S. Günüç, "Dijital Oyun Bağımlılı̆̆ında Aile Yapılarının Bazı Değişkenler Açısından İncelenmesi," 3 Uluslararası Teknoloji Bağımlılı̆̆ı Kongresi, Yeşilay, İstanbul. May, 2016.

[18] M.B. Horzum, "İlköğretim Öğrencilerinin Bilgisayar Oyunu Bağımlılık Düzeylerinin Çeşitli Değişkenlere Göre İncelenmesi," Ĕgitim ve Bilim, vol. 36, no. 159, pp. 56-68, 2011.

[19] B. Eni, "Lise Öğrencilerinin Dijital Oyun Bağımlılığı ve Algıladıkları Ebeveyn Tutumlarının Değerlendirilmesi," Haliç Üniversitesi, Sosyal Bilimler Enstitüsü, Yüksek Lisans Tezi, İstanbul, 2017.

[20] E. Köroğlu, Dsm-V: tanı ölçütleri başvuru kitabı (E. Köroğlu. Çev.). Washington DC: Amerikan Psikiyatri Birliği, 2013. 
[21] Caplan SE., "Problematic internet use and psychosocial wellbeing: Development of a theory-based cognitivebehavioral measurement instrument," Comput Hum Behav., vol. 18, no. 5, pp. 553-75, 2002.

[22] Caruso D., Critics are picking apart a professor's study that linked Internet use to loneliness and depression. New York Times. 1998.

[23] Chak K. and Leung L., "Shyness and locus of control as predictors of internet addiction and internet use," Cyberpsychology \& Behavior, vol. 7, no. 5, pp. 559-70, 2004.

[24] W. B. Hagedorn and T. Young, "Identifying and Intervening with Students Exhibiting Signs of Gaming Addiction and Other Addictive Behaviors: Implications for Professional School Counselors," Professional School Counseling, vol. 14, no. 4, pp. 250-260, 2011.

[25] S. Gürmen, "Teknoloji Bağımlılığı, "Ailemiz ve Çocuklarımız,” 3. Uluslararası Teknoloji Bă̆ımlılı̆̆ Kongresi. Yeşilay, İstanbul, May, 2016.

[26] S. Chiu, J. Lee, and D. Huang, "Video game addiction in children and teenagers in Taiwan," Cyberpsychology \& Behavior, vol. 7, no. 5, pp. 571-581, 2004.

[27] A.A. Ceyhan, "Predictors of problematic internet use on Turkish university students," CyberPsychology \& Behavior, vol. 11, no. 3, pp. 363-366, 2008.

[28] N. Karasar, Bilimsel Araştırma Yöntemi. Ankara: Nobel Akademik Yayıncılık, 2014.

[29] M. Özgenel, et al., "Social Media Addiction Scale for Adolescents: Validity and reliability study," Addicta: The Turkish Journal on Addictions, vol. 6, no. 3, pp. 631-664, 2019.

[30] G. Anlı and İ. Taş, "Ergenler İçin Oyun Bağimliliği Ölçeği Kısa Formunun Geçerlik ve Güvenirlik Çalişmasi," Electronic Turkish Studies, vol. 13, no. 11, pp. 189-203, 2018.

[31] N. B. Epstein, et al., "The McMaster Family Assesment Device," Journal of Marital and Family Therapy, vol. 9, no. 2, pp. 171-180, 1983 .

[32] I. Bulut, Aile değerlendirme ölçeği el kitabı. Özgüzeliş Matbaası, Ankara, 1990.

[33] D. Karacaoğlu, "Çocuklarlarda Bilgisayar Oyun Bağımlılığı ile Aile İlişkileri Arasındaki İlişkinin İncelenmesi," Sabahattin Zaim Üniversitesi, Sosyal Bilimler Enstitüsü, Yüksek Lisans Tezi, İstanbul, 2019.

[34] U. Demir, "Sosyal medya kullanımı ve aile iletişimi: Çanakkale'de lise öğrencileri üzerine bir araştırma," Journal of Selcuk Communication, vol. 9, no. 2, pp. 27-50, 2006.

[35] R. Balıkçı, "Çocuklarda ve ergenlerde çevrimiçi oyun bağımlılığı ve agresif davranışlar arasındaki ilişkinin incelenmesi," Master's thesis, Fatih Sultan Mehmet Vakıf Üniversitesi, Sosyal Bilimler Enstitüsü, 2018.

[36] V. Okumuş, "Çocukların sosyal medya kullanımları ile ebeveyn tutumları arasındaki ilişkinin incelenmesi," Master's thesis, İstanbul Ticaret Üniversitesi, 2018.

Int. J. Eval. \& Res. Educ. Vol. 9, No. 4, December 2020: 979 - 986 